\title{
Acute Myeloid Leukemia with Mutated RUNX1
}

National Cancer Institute

\section{Source}

National Cancer Institute. Acute Myeloid Leukemia with Mutated RUNX1. NCI Thesaurus.

Code C129786.

De novo acute myeloid leukemia with RUNX1 gene mutation, not associated with myelodysplastic syndrome-related cytogenetic abnormalities. 